\title{
Students' Speaking Problem at the Fourth Semester of English Study Program in Sembilanbelas November Kolaka
}

\author{
Netty Huzniati Andas \\ 22akhmadlatif@gmail.com \\ Yuni Rutniatyanti \\ Yunirutniyanti@gmail.com
}

Universitas Sembilanbelas November Kolaka

\begin{abstract}
The objectives of this research were to find out the students' speaking problems at the fourth semester of English Study Program in Sembilanbelas November University and factors affecting them. This research employed case study with qualitative approach. There were 26 participants at class A of the fourth semester in English Study Program. Those participants were selected through purposive sampling technique. To gain the data interview, observation sheet, and students' transcript report were used. The result showed that there were four problems that were experienced by students at the class A fourth semester first was inhibition, when speaking the students tend to be worried about making mistake, getting criticism from others, and shyness. The second was lack of ideas; the students tend to be silent participants in speaking due to lack of vocabulary and grammar. The third was low or uneven participation in speaking. Here, only few students participate the speaking activities while other remaining silent. And the last was students got difficulty to speak because of the influencing of mother-tongue use. There were two factors affecting the students' speaking ability such as internal and external factors. The internal factors here the students have low motivation in speaking while the external factors were the students' condition in the classroom
\end{abstract}

Keywords: Speaking, Speaking Problems, Factors affecting in Speaking

\section{INTRODUCTION}

In learning English, there are four skills that students should be mastered. They were listening, reading, writing, and speaking. Each skill has their own goal to be reached as the requirements of mastering English. One of important language skill is speaking which is considered as productive skill. As a productive skill, speaking produces verbal or nonverbal utterance to convey the meaning that involves an interactive process, producing and processing information. Speaking is not only making the right sounds, choosing the right words or getting the construction grammatically correct. Nonetheless, speaking is more complex as it covers many components (Phonology, Morphology, Syntax, and Discourse) and units (text, utterance, clause, phrase, words, etc) which must function together when learner speak English (Van Lier ,1995 in Sriprabha, 2015)

In the same line, Arung (2016) revealed that speaking become the important part in English because through speaking people can interact with other to express their opinion. In addition, 
Arung stated that as the main key of interaction, speaking can be a justification from other people that we master English, because the first assessment of people toward person who learn language is her/his speaking ability, how does she/he talk, what are they discussed, and how are the style of speech. Especially for English students, the ability to speak will be the very first skill being noticed when they are in the middle of society, because it has been people's perception that if you are an English student means you are able to speak in English fluently

The teaching of speaking skill is worthy either due to the large number of students who want to study English in order to be able to use English for communicative purposes. Richards and Renandya's (2002) admitted that the large number of language learners in the world have a greatest increasing in learning English in order to develop proficiency in speaking. Moreover, the students of second foreign language education programs are considered successful if they can communicate effectively in the target language.

Moreover, speaking skill not only useful in classroom activity but also speaking is pivotal for students' career in the future due to speaking skill has become one of considerations for employing people in many jobs. As Baker (2000) by learning to speak English well, students gain a valuable skills which can be useful in their life and contribute to other communities and countries.

Regarding to the current phenomenon in learning English as Foreign Language, most of students cannot speak English well as speaking consider being difficult since it occur in real time where there are two or more people talk each other about things that they think are mutually interesting, each participant both a speaker and listener taking turn to speak in which they have to provide any contribution, monitoring each other while speaking, and giving immediate feedback from one's another. Moreover, because spoken communication happens in real time the opportunity to plan and edit what we wish to say is limited, unlike in written communication we have time to plan or revise what we want to write (Megawati, 2016).

In addition the teaching of speaking skill is considered to be difficult one since in order to be able to communicate effectively the learners are required to know its grammatical and semantic rules. Learners must also acquire the knowledge of how native speakers use the language in the context of structured-interpersonal exchange, in which many factors interact. Therefore, it is difficult for EFL learners to speak the target language fluently and appropriately.

As the ability to speak English is very complex task considering the nature of what is involved in speaking, not all of the students in an EFL speaking class have the courage to speak. Nakhala (2016) found that the students of English are not highly competent in speaking because of their fear of making mistakes. Other finding was conducted by Januariza and Hendirani (2016) stated that the students fail to join the English discussion because of their vocabulary problems and fear of making mistakes resulting in their inability to speak English well. In addition, they said that the students find English is stressful activity especially if they have to perform something using English.

Ur (1991) arranged four problems that hindrance students to speak well, they are inhibition, nothing to say, low or uneven participation, and the mother-tongue use. Inhibition is a psychological factor that commonly experienced by the learner in speaking activity. Nothing to say occurs when the students have no idea to say or share with others. Then, low or uneven participation happens when one talkative student dominates the activity in the classroom, therefore, the participation is unequal and other students do not get enough opportunity to contribute any idea or express their main. The last is mother-tongue use means the interference of first language in the speaking activity will negatively affect the students' speaking ability in the target language.

Finding out students' problem in speaking bring more benefit for a lecturers due to they can provide some solution to overcome those problems, thus this research was carried out to give information about students' problem in speaking along with factors affecting them. This research was held on class A at the fourth semester of English Study Program because from the preobservation, researchers found that commonly they were not be able to speak English well. When they were in classroom most of them could not express their ideas, they just kept silent and did not want to practice speaking. While in that semester the students had passed Speaking 1 and Speaking 2 subject. Moreover, as an English teacher in the future, they demand to use English to interact 
with their students in teaching and learning process. So that's why the researchers were eager to figure out what students' hindrance in speaking which this information could be used by the lecturer to encourage students to speak.

In addition, English Study Program always become as representative from USN Kolaka to compete in Debate competition in National level such as; NUDC and English Expo, however they achievement was still lower that other state university. One of the problems was because the students lack of ability in speaking, most of them said that we had all of the ideas to convey but it was very had to deliver them in English. Therefore, by recognizing the students' problems in speaking, the lecturers and the students will get some information about those problems so they will provide any solution to cope with the problems and the students' speaking ability can be increased either.

This kind of research had been conducted by several previous researcher likes; Juhana (2012) who found out psychological factors were the most affecting students' ability to speak in the classroom. In line with Juhana, Hadijah (2014) tried to investigate English students' problem in Islamic Boarding School Program at Stain Samarinda. She found that In Speaking, the students were feel ashamed at performing English, students had limited vocabulary, students get difficulties in using the right grammar, students are interested to learn Arabic rather than English, and lack of speaking practice. However, this current research not only focused to find out students' problem in speaking or specify

This current research almost similar to the both of previous researchers, however, this current research not only focused on finding out students' problem in speaking or specify the psychological factor as hindrance the students to speak well. Here, this research aimed to dig information about students' problem in speaking then tried to examine its affected factors either internal or external factors which covers students' psychological factors as well. Therefore, the researcher believe that the result of this research give many benefit in education field especially for teacher and students.

\section{METHOD}

This research was descriptive research with qualitative approach which aimed to find out information about students' problem and its factor that affected them. This research was conducted in English Study Program USN Kolaka, the researcher chose purposively 26 students of class A at fourth semester in English Study Program semester as the participant in this research, they consist of 3 males and 23 females. To gain the data, students' transcript reports, field not observation, and interview guideline were used. To collect the data, firstly the researcher did a document analysis of students' transcript report on speaking subject. This helped the researcher to identify students classify students' ability in speaking English. Next, the researcher observed students activity in teaching and learning process, in observation the researcher only noticing those students who had a low ability in speaking. It was aimed to find students' real difficulties in speaking activity. The last was the researcher conducted an interview session, here the researcher chose to interviewed three (3) informants who considered had low ability and inactive participants in speaking, it was aimed to discover their main difficulties in speaking along with its affected factors. To analyze the data the researcher used some stages in qualitative analysis. First was familiarizing and organizing, in this stage the researcher familiarize the data through reading the notes and students' transcript, reviewing the videotapes, and listen the audiotapes repeatedly. Then, coding and reducing, in this step, the researcher classified the problems found based on the grand theory of presenting in this research. The last was interpreting and representing the finding. In interpreting the data, the researcher bringing out the meaning, telling the story, providing and developing plausible explanation related to the objective of this research. While representing was how the researcher present the data through descriptive dail. 


\section{RESULT AND DISCUSSION}

From the data analysis, the researcher found that there were several problems which experienced by the students in class A at fourth semester of English Study Program. Those problems were presenting in the following table;

\section{Table 3.1. Students' Speaking Problem}

\begin{tabular}{|c|c|}
\hline Problem 1 & Inhibition \\
\hline $\begin{array}{l}\text { Worry of } \\
\text { making mistake }\end{array}$ & $\begin{array}{l}\text { "Kekhawatirannya itu tentang pronunciationnya, ....misalnya kita salah } \\
\text { sebut satu kata saja beda maknanya" (Interview A8). “...Kan kalau bahasa } \\
\text { Ingris takutnya salah pengucapannya" (Interview A36). } \\
\text { "Saya juga takut, terus saya malu juga sama teman-teman (Interview C8). } \\
\text { "Takut sama teman-teman kalau saya salah berbicara" (Interview C10). }\end{array}$ \\
\hline $\begin{array}{l}\text { Worry about } \\
\text { getting criticism }\end{array}$ & $\begin{array}{l}\text { "Selain itu merasa takut di kritik. Saya sering di terwai sama teman-teman } \\
\text { karena masalah pronunciation. Akhirnya saya tidak berani bicara didepan } \\
\text { kelas. Tadinya sudah ada keinginan tapi karena takut jadi tidak jadi lagi" } \\
\text { (Interview C12) }\end{array}$ \\
\hline Shyness & $\begin{array}{l}\text { "Saya biasa demam panggung dan paknik (Interview B10). Iya malu. Suka } \\
\text { tiba-tiba blank ee.. apa suka lupa (Interview B12). } \\
\text { "Saya juga takut, terus saya malu juga sama teman-teman (Interview C8). } \\
\text {...Sering ditertawai samateman-teman dikelas. Masalah pronunciationku, } \\
\text { juga, malu, deg-degan, sama rasa takut akhirnya tidak mau berbicara" } \\
\text { (Interview C18). }\end{array}$ \\
\hline Problem 2 & Nothing to say \\
\hline $\begin{array}{l}\text { Lack of } \\
\text { vocabulary }\end{array}$ & $\begin{array}{l}\text { "Iya jadi yang pertama yang jadi masalahnya itu vocabulary..." } \\
\text { (Interview A4). "...Cuma memang kendalanya ada di vocabulary" } \\
\text { (Interview A16). } \\
\text { "Jadi kendala saya itu di vocabulary...” (Interview B4). "Vocabulary saya } \\
\text { juga kurang" (Interview B30). } \\
\text { "Problem yang pertama itu kak, kurang kosa kata..." (Interview C6). "Iya } \\
\text { karena memang saya kurang kosa kata dan saya pahamnya bahasa } \\
\text { Indonesia. Lebih mudah kak" (Interview C16) }\end{array}$ \\
\hline \multirow[t]{2}{*}{$\begin{array}{l}\text { Lack of } \\
\text { grammar }\end{array}$} & $\begin{array}{l}\text { Yang jadi masalahnya itu vocabulary, terus .... dan juga penentuan } \\
\text { struktur katanya bagaimana, ehm.. jadi itu yang jadi masalahnya. } \\
\text { (Interview A4). } \\
\text { Jadi kendala saya itu di vocabulary, ee.. grammar, dan pronounciation } \\
\text { (Interview B4) ...Karena lebih muda kalau pakai bahasa Indonesia } \\
\text { ketimbang bahasa Inggris harus dipikir dulu struktur katanya... (Interview } \\
\text { B34) }\end{array}$ \\
\hline & Low or uneven participation \\
\hline
\end{tabular}




\begin{tabular}{|l|l|}
\hline Problem 3 & $\begin{array}{l}\text { "Pokoknya hanya teman-teman yang bisa saja yang sering berbicara } \\
\text { didalam kelas, akhirnya tidak punya kesempatan. Maksudnya yang tidak } \\
\text { bisa" (Interview C28). "Maksudnya hanya yang bisa berbahasa Inggris } \\
\text { itu yang berbicara, akhirnya yang lain yang merasa tidak bisa tidak sering } \\
\text { di tunjuk" (Interview C30). }\end{array}$ \\
\hline Problem 4 & $\begin{array}{l}\text { Mother tongue use } \\
\text { "Bahasa Indonesia lebih cepat pengucapannya, kalau bahasa Inggris } \\
\text { dan juga bahasa Indonesia lebih dimengerti sama teman-teman..." } \\
\text { (Interview A36). } \\
\text { "Karena lebih muda kalau pakai bahasa Indonesia ketimbang bahasa } \\
\text { Inggris harus dipikir dulu struktur katanya, dicari kosa katanya" } \\
\text { (Interview B34). } \\
\text { "Iya karena memang saya kurang kosa kata dan saya pahamnya bahasa } \\
\text { Indonesia. Lebih mudah kak" (Interview Cl6) }\end{array}$ \\
\hline
\end{tabular}

The table above showed that there were four problem that hinder students to speak in English such as Inhibition, nothing to say, low or uneven participation, and mother tongue use. First problem was Inhibition which influenced by three major factors such as; students were worrying of making mistake, the students admitted that when speaking activity occur in classroom most of them feeling worry to sound silly in pronouncing some words in English even less the way to pronounce a word in their first language is differ from the target language. Furthermore, being laughed at by their friends was also made them reluctant to speak, therefore they chose to remain silent. Next, students were worrying about getting criticism, in this case, the students inhibited to speak English because they won't to get any critics either form teacher or friend, sometimes criticism appeared when they language used ungrammatically order and pronunciation they produced sounds weird. As result student stop participating in speaking activity. The last was shyness, here, the students confessed that feeling shy to speak English emerged when they began to speak English every eyes in the classroom stared at them made their mind went blank and forgot what to say.

Next, nothing to say was arose when students have some ideas in their mind; nonetheless they did not have enough vocabulary and good grammar in English, so that they remain to be silent in a classroom. The students stated that one of difficulties in speaking English was when they didn't have sufficient vocabulary to engage with the topic discussing, however, the students who memorized a lot vocabularies did not participate well in discussion due to they didn't have any knowledge to arrange the word into a good sentences based on the rule of appropriate grammar.

Then, Low or uneven participation occurred when one student dominated the classroom due to his/her ability was better than others. The students confessed that most of them did not have any change to perform in speaking activity, only few active students dominate the whole discussion. Most of students felt ignore by the teacher during the discussion due to they never participating well throughout speaking activity. The teacher simply noticed an active one.

The last was mother tongue use, this problem happened when students prefer to use first language then target language in speaking activity. The students said that using Bahasa was easier for them to express the ideas, meanwhile to convey opinions in English was very hard for them since they lack of vocabulary, grammar, and pronunciation. 
Table 3.2. Factors Affecting the Problems

\begin{tabular}{|c|c|}
\hline Factors & Inhibition \& nothing to say problems \\
\hline Internal & $\begin{array}{l}\text { "Awalnya memang saya tidak ada niat masuk bahasa Inggris, karena } \\
\text { tidak suka bahasa Inggris. Yang kedua, kenapa nda mau belajar atau } \\
\text { mau tahu lebih, ee.. keinginan masuk bahasa Inggris itu karena keinginan } \\
\text { orang tua ... Jadi kalau keinginan mau belajar itu belum ada sampai } \\
\text { sekarang" (Interview A22). } \\
\text { "Iya mungkin karena dari awal memang tidak suka bahasa Inggris kak. } \\
\text { Memang dari awal tidak tertarik dengan bahasa Inggri. (Interview B40) } \\
\text { "Faktor dari diri sendiri kak (Interview C20) ....Pertama karena malas } \\
\text { belajar, terus tidak ada dorongan dari teman-teman. Ada teman satu kos } \\
\text { tapi tidak ada dorongan. Kurang motivasi juga kak (Interview C22). } \\
\text { Emm... dari awal memang tidak tertarik dengan bahasa Inggris. Jadi } \\
\text { keinginan belajarnya kurang”"(Interview C24). }\end{array}$ \\
\hline & Low or uneven participation $\&$ mother tongue use \\
\hline External & $\begin{array}{l}\text { "Iya. Pokoknya hanya teman-teman yang bisa saja yang sering berbicara } \\
\text { didalam kelas, akhirnya tidak punya kesempatan..." (Interview C28) } \\
\text { "Maksudnya hanya yang bisa berbahasa Inggris itu yang berbicara, } \\
\text { akhirnya yang lain yang merasa tidak bisa tidak sering di } \\
\text { tunjuk"(Interview C30) } \\
\text { "...dan juga bahasa Indonesia lebih dimengerti sama teman-teman" } \\
\text { (Interview A36). "Karena lebih mudah disebutnya.... Iya, dan karena } \\
\text { terbiasa juga" (Interview B38) }\end{array}$ \\
\hline
\end{tabular}

The table above revealed that students' problem in speaking were affected by two major factors; internal and external factors. First, Internal factors covered Inhibition and nothing to say. Most of students declared that those difficulties occurred because they lack of motivation to learn English, some students said that English major was not their passion, it was belong to their parents, and the others stated that they didn't have any desire to improve their ability in English especially speaking due to they were not interesting to learn English. Secondly external factors involved low or uneven participation and mother tongue. Most of students confessed that classroom condition was the main basis to use Bahasa in teaching and learning process because it was easier and understandable than English. In addition, some students either declared that they were not interested to participate well in speaking activity due to the teacher did not give any opportunity for them to express ideas.

\section{Discussion}

After analyzing the data, the researchers found there were four problems that experienced by students in speaking, such as; Inhibition, nothing to say, low or uneven participation, and mother tongue use. Meanwhile, those problems were affected by internal and external factors which hinder students to speak well in English.

\section{Inhibition}

The first problem that occurred at fourth semester class A was Inhibition. Inhibition is a psychological factor that commonly experienced by the learner in speaking activity (Juhana, 2012). This research found that inhibition appeared due to the students worrying about making mistake, fearful at critics, and shyness. First was worrying about making a mistake. It was 
primary reason of inability students to speak English In classroom. Feeling afraid of making mistake is related to the issue of correction and negative evaluation either from peers or teacher (Nakhalah 2016). In this research, most of the students stop participating the speaking activity due to they were afraid of looking foolish in front of their friends or others laughed at them when they made mistake in speaking. Here, the most common mistake that students made in speaking were grammatical and pronunciation, those mistakes inhibited students to express their ideas in the classroom, they tend to be silent instead of taking part in discussion since they thought having mistaken in grammar and pronunciation was ashamed. Juhana 2012 revealed that as psychological factors, fears of mistake negatively influence students' speaking activity in classroom. Therefore, creating the harmonious atmosphere in classroom is very important to reduce students' fearful. In addition, emphasizing to the students that mistake in speaking is commonly happen in learning process can help them to carry out a success communication in English.

The second was fear of getting critics, commonly getting criticism is supposed to be normal for students in learning process, by criticism from others they knew whether they are wrong or not (Ur, 1991 in Megawati 2016,). But unfortunately only few students thought that way, mostly they regarded that criticism from others was the way to show their weakness, that's why in speaking students tend to be passive participant, they did not have any braveness to deliver even a simple ideas. Afraid of criticism also made the students anxious to say something because mostly students feel that their English is bad and they cannot speak English well.

The last problem that inhibited students to speak in English was shyness. Shyness is an emotional feeling that many students expreinced when they are required to speak in English class. This indicates that shyness indicateed as source of problem in students' learning activities since the students were not able to in the classroom especially in the class of speaking. Therefore, paying attention on this aspect is also quite important in order to help the students do their best in their speaking performance in the classroom. The researcher found that students often felt shy in expressing their idea by using English in front of the class. From the result of interviewed students admitted that when the teacher asked them to speak in front of the classroom most of them got nervous and lost the ideas to speak. In addition, the students were not confidence and tend to be shy because most of them felt intimidating when speaking English in front of their friends or teacher.

\section{Nothing to Say}

This problem occurred when the students have no idea to say or share with others. Although, the learners are not feeling shy or anxious anymore, they will remind to be silent participant in the classroom since the students did not have something to say (Ur, in Juhana 2012). In this research, the students have no idea to share with other not because of uninteresting topic which presented by the teacher, it was because most of the students lack of vocabulary and grammar, therefore they chose to be silent even they were interested to the topic.

First was lack of Vocabulary, as one of language elements in English, vocabulary has an important role in speaking, communication can run well if someone has enough vocabulary. Scott (2002) states that without vocabulary nothing can be conveyed and people will see the most improvement if they learn more words which can make them say almost anything. In this research, the majority of students got problems in mastering the vocabulary, the admitted that to convey ideas in English they tend to choose Bahasa or they opened the dictionary to translate the word by word. Some students also revealed that it was hard for them to speak even a simple sentence in English.

The second was Lack of Grammar, like vocabulary, grammar also prominent element in English especially in speaking since grammar is the system of rules that construct the formation and connection of every word in sentence (Harmer 2002). Based on the result of observation, researcher found that most of students felt hard to speak in English due to the absence of knowledge in grammar. It was indicated that students were not able to make even a simple sentences such a verb's third-person singular form, and others. For Instance they used "do" 
when the subject was "He", or they did not use verb 2 when they formed a past tense. Moreover, the result of interview showed that some students reluctant to learn about grammar because they thought when speak in English it was necessary to learn the grammar, as long as the interlocutor understood the meaning then the communication might be occur.

Both of the problems above were affected by internal factors which came from the students itself. As an internal factor students' motivation gave a big contribution to the students' success in learning English. Grab and Stoller (2003) in Humaera (2015) mentioned that motivation is a crucial point to learn that has significant contribution associated with interest, self-efficacy, involvement, and self-concept. In line with Grab and Stoller, Nunan (1999) in Nakhala (2016) revealed that motivation is an important to be noticed since it affect students' reluctant in speaking. In this sense, motivation determines preparedness of learner to have a communication. Most of the students lack of motivation to learn English especially speaking. They thought that speaking was difficult since the way to pronounce each word were really different from Bahasa, therefore it hard for them to increase either vocabulary or grammar. Some students confessed that it hard for them to memorize many vocabularies in English, so they tend to open dictionary to find the meaning of unfamiliar word. Likewise grammar, students felt complicated about the change of word construction in English which was very different from Indonesian's formation. In addition, the students feeling of boredom in classroom made them demotivated to actively participate in speaking activity moreover only active student dominate the activity, so they chose to remain silent. The last, the students had no any preparedness therefore they got anxious when teacher asked them to perform speaking in front of their friends.

Realizing an essential of motivation, students demanded to increase their motivation in learning English to create their own way to deal with their own development. If this happens the process of teaching and learning become easier and full of fun because they actively involved in the lesson. Furthermore to motivate students to learn well and actively communicate in English, teachers should have passion, creativity and interest in their students. In other words, students' motivation is really influenced by the teachers' teaching performance. Therefore, it is important that teachers also show enthusiasm in their teaching performance.

\section{Low or Uneven Participation}

The third problem that hindered students to speak was low or uneven participation. It appeared that when one talkative student dominates the activity in the classroom, therefore, the participation is unequal and other students do not get enough opportunity to contribute any idea or express their main. As Ur (1991) stated that low or uneven participation is where only one or two participant can talk at a time. From the observation result, the researcher found that in teaching and learning process all of the students got equal chance to engage in speaking activity. However, students who had a good ability in speaking tend to be more active in classroom, while the others just remaining silent. In line with the result of interviewing, researcher found that some students did not participate actively in classroom because there were few students dominate the activity. Some students also wanted to initiate to deliver idea then the time provided had run out, so they just kept quiet and lost opportunity to speak.

The factor that caused this problem occurred was an external factor. An external factor was outside influence that might impact students in learning English. From the result of interviewing, the researcher found that classroom condition were trigger factor so students were not optimal in speaking. They felt that situation in classroom did not allow them to speak because there were few students dominate the discussion. Those students always got chance to talk since their ability in speaking were better others. Meanwhile, inactive participants were only remaining silent although they want to initiate to speak.

\section{Mother Tongue Use}

The last problem at class A of fourth semester in English Study Program was mother tongue use. According to Khati (2011) commonly mother tongue use is as a language learnt before any other language has learnt, people learn mother tongue since a child naturally, he/she 
picked this language in social environment around her/him. The researcher found that most of students prefer to use mother tongue in classroom discussion, in their mind, mother tongue was easier to use, they did not need to be bother to interpret word by word in English or compose some right sentences that were appropriate in English. In addition, researcher found that some students use English in the classroom if the lecturer asked them to present in front of the classroom, yet they just speaking a little in English then turn to use mother tongue for the whole discussion. In line with that issue, Ur (1991) stated that the use of mother tongue in classroom might negatively influence students' speaking ability, In this regard, allowing or giving tolerant to the students in using their first language during the class dicussion will make them not effectively to communicate in English as a consequence the communicative competence in the target language cannot be achieved.

The factor that caused this problem was from the students' external factor. They felt that the condition in the class forced them to speak their mother tongue. This was because most of them did not really understand English. As what the researcher found after observing the students speaking activity, the students were seemed so comfortable to speak by using their mother tongue. The researcher found that when student had tried to speak English, but their friend asked them by using mother tongue, then the student directly turned to speak using mother tongue in delivering some ideas.

\section{CONCLUSION}

Based on the research finding, it can be concluded that, there were four problems that found on class A at fourth semester of English Study Program in Sembilanbelas November University and two affected factors. Those problems were inhibition, nothing to say, low or uneven participation, and mother tongue use. Inhibition was a psychological factor that commonly inhibited students in speaking activity, it included; Worry about making mistake, Worry about getting criticism, Shyness. Nothing to say was when students did not have something to say because of lack of idea, lack of vocabulary, and the absence of grammar knowledge. Low or uneven participation was when one or two students dominate the discussion while others had unequal participation in the classroom. Mother tongue use was when students prefer to use their mother tongue than English in speaking activity. The Problems were affected by Internal and External factor. Internal factor was a factor from the students itself, likes some of the students low motivation in learning English because they taught English was difficult. Meanwhile, external factor was outside influence such as a classroom condition that make them lost opportunity to speak in English.

Based on the research finding, the researcher suggested both of lecturer and suggestion. The students' motivation influence their ability to speak in English, most of students in class A had low motivation in learning speaking, they tend to be inactive participant during the classroom activity. Therefore, the lecturer must create a new innovation in teaching speaking such as provide the students with the media to attract them in learning speaking. Lecturer should give equal participation to all students, so there is no one students dominate the classroom. In addition, creating a good atmosphere in classroom may reduce students' anxiety to speak.

\section{REFERENCES}

Arung, Fernandes.(2016). Improving the Students' Speaking Skill through Debate Technique. Jurnal of English Education, 1(1), 71-72.

Baker, J., \& Westrup, H. (2000). English Language Teachers' Handbook: How to Teach Large Classes With Few Resourches ( $8^{\text {th }}$ ed). New York: Bloomsbury. 
Hadijah, Sitti. (2014). Investigating the Problems of English Speaking of the Students of Islamic Boarding School Program at STAIN Samarinda. Dinamika Jurnal. 14(2), 147-156. DOI: https://doi.org/10.21093/di.v14i2.16

Humaera, Isna. (2015). Inhibition in Speaking Performance. Journal of the Association for Arabic and English. 1(1), 31-50.

Harmer, Jeremy. (2002). The Practice of English Language Teaching. Longmand: England.

Januariza, Y.,\& Hendriani, S. Students' Anxiety in Learning Speaking. Paper presented at Proceeding of the Fourth International Seminar on English Language in Teaching (ISELT-4), 468-474

Juhanna. (2012). Psychological Factors That Hinders Students from Speaking in English Class (A case study in a Senior High School in South Tanggerang, Banten,Indonesia). Journal of Education and Practice. 3(12), 100-110

Khati, A.R. (2011). When and Why of Mother Tongue Use in English Clasroom. Journal of Nelta. 16(1-2), 42-51. https://doi.org/10.3126/nelta.v16i1-2.6128

Kothari, C.R. 2004. Research Methodology. Methods and Techniques. New Delhi: New Age International Publisher.

Megawati, F.,\& Mandarani, V. (2016). Speaking Problems in English Communication. Paper presented at Proceeding of the $1^{\text {st }}$ English Language Teaching Learning Conference (ELTIC): Its Trend of Curriculum Challenges to Face ASEAN Economic Community, English Education Program, Muhammadiyah university of Purwerejo.

Nakhala, M.M.A. (2016). Problem and Difficulties That Encounter English Language Students at Al Quds Open University. International Journal of Humanities and Social Science Invention. 5(12), 96-101.

Scott, Thormbury. (2002). How to Teach Vocabulary. England: Pearson Education Limited.

Sriprabha, M. (2015). A study on Mother Tongue Influence in Englsih Communication. International Journal of English Literature and Culture. 3(11), 296-300. DOI: 10.14662/IJELC2015.100

Tuan, N.H. \& Mai, T.N. (2015). Factors Affecting Students' Speaking Performance at LE Thahn Hien High School. Asian Journal of Education Research. 3(2), 8-23

UR, Penny. (1991). A Course in Language Teaching (Practice and Theory). Cambridge: Cambridge University Press. 